\title{
KONSEP MANAJEMEN BISNIS DAN MARKETING SYARIAH (Elaborasi Terhadap Lembaga Pendidikan Islam)
}

\author{
Oleh: \\ H. Mohammad Kuswadi ${ }^{1}$ \\ Email: mkuswadi3@gmail.com
}

\begin{abstract}
Business according to Islam is a lawful thing even highly recommended. Business was even carried out by the prophet and the Prophet's apostle who was a very respected merchant of his day. Islam allows business as long as it is not things that lead to usury, gambling, the provision of products or services that contain illicit goods. In business, of course, a marketing is needed. The basis of Shari'ah marketing activities must be; 1). The spirit of worship to Allah Swt, 2). Try as much as possible for the common welfare, 3). Not for the benefit of the group let alone their own interests. Marketing is an important aspect in a business practice. Business practices not only focus on the problem of product sales (sales performance orientation) that are quality and meet the needs and desires of customers, but there is also a process of communication that continues to proactively foster a series of business networks through marketing products or services that can impress customers (customer loyality). Marketing is often interpreted as sales. Understanding of marketing actually wider and sales activities. Sales are a part of marketing activities. Marketing does not only cover the activities of selling goods or services, but includes several other activities that are quite complex such as; 1). research on consumer behavior, 2). research on market potential, 3). activities to develop new products, and 4). distributing and promoting goods sold. Marketing strategy is a form of directed plan in the field of marketing, to obtain an optimal result. The marketing strategy contains two separate but closely related factors, namely, the target market and the marketing mix. These two factors are closely related. The target market is the target to be addressed, while the marketing mix is a tool to get to that target. Marketing strategy has a broad scope in the field of marketing. Among them are strategies in competition, product strategies, and so on.
\end{abstract}

Keywords: Management, business, sharia marketing, Islamic educational institutions

${ }^{1}$ Dosen Sekolah Tinggi Agama Islam Syaichona Moh. Cholil Bangkalan Madura. 


\section{Pendahuluan}

Islam memandang bahwa berusaha atas bekerja merupakan bagian integral dari ajaran Islam. Rasulullah juga memandang pentingnya bekerja dalam rangka mencari nafkah. Bekerja adalah bagian dari ibadah dan jihad jika seseorang tetap bersikap konsisten pada aturan Allah Swt., memiliki niat yang suci dan dilakukan untuk memenuhi kebutuhan diri, keluarga bahkan masyarakat dan negara. Semua kegiatan atau objek yang dikerjakan sebagaimana bayangan di atas merupakan bagian, unsur, proses dan tindakan dari kegiatan yang dikenal dengan istilah bisnis. Kata bisnis dapat diartikan sebagai usaha perdagangan. Bisnis merupakan kegiatan yang melibatkan kedua belah pihak untuk memperoleh manfaat yang dilandasi dengan prinsip saling setuju, baik secara risiko maupun keuntungan. Karena mengandung risiko maka pelaku bisnis perlu melakukan langkah-langkah manajemen yang bagus guna meminimalisir risiko yang dihadapi.

Boone dan Kurtz bisnis adalah aktivitas dan usaha untuk mencari keuntungan dengan menyediakan barang atau jasa yang dibutuhkan bagi sistem perekonomian. ${ }^{2}$ Keuntungan atau laba ini juga memiliki pengertian yang bervariasi, misalnya dari sudut pandang akuntansi laba merupakan selisih antara penerimaan dengan biaya operasional yang digunakan selama menjalankan bisnis dalam periode tertentu. Secara umum laba merupakan imbalan bagi pebisnis. Laba merupakan insentif bagi seseorang yang menciptakan, memproduksi, memperluas dan memasarkan barang atau jasa secara kompetitif, berkualitas tinggi, dan konsisten.

Menurut Gamal $^{3}$ prinsip-prinsip dan petunjuk-petujuk dalam masalah bisnis yang dapat diklasifikasikan dalam 3 bagian yaitu:

1. Kebebasan dalam usaha

Salah satu bentuk kebebasan dalam usaha mencari rezeki Allah adalah bekerja. Bekerja keras dengan penuh tawakal sangat dianjurkan oleh Islam dan termasuk amal ibadah istimewa. Ketika Rasulullah Saw,

${ }^{2}$ Asnawi, Nur dan Fanani, Muhammad Asnan. 2017. Pemasaran Syari'ah: Teori, Filosof, dan Isu-isu Kontemporer. Depok: Rajagrafindo. Hlm 76.

3 Asnawi, Nur dan Fanani, Muhammad Asnan. 2017. Pemasaran Syari'ah: Teori, Filosof, dan Isu-isu Kontemporer. Depok: Rajagrafindo. Hlm 78. 
ditanya tentang amal manakah yang istimewa? Jawab beliau adalah bekerja dengan keterampilan tangan sendiri, bahkan Rasulullah Saw, menegaskan:

"Bukanlah orang yang terbaik di antara kalian orang yang rajin beribadah mencari pahala akhirat dengan meninggalkan aktivitas bekerja untuk kepentingan kehidupan dunia, dan bukan pula orang yang terbaik di antara kalian orang yang rajin bekerja dengan meninggalkan aktivitas ibadah. Orang yang terbaik di antara kalian adalah yang melaksanakan keduanya, rajin bekerja dan rajin pula beribadah. Sebab kekayaannya dapat dijadikan sarana meraih kebahagiaan akhirat. Karenanya, janganlah kalian menjadi manuia pemalas" (HR Ibnu Asakir dari Anas).

Falsafah tatanan yang dianut dalam Islam berkenaan dengan kebebasan berusaha (bekerja) adalah keadilan dan keseimbangan. Inti dari kegiatan bisnis yang dilakukan adalah tercapainya kebaikan dan kebahagiaan di dunia dan akhirat sebagaimana do'a yang dipanjatkan Rasulullah Saw kepada Allah Swt:

"Ya Tuhannku berilah aku kebaikan di dunia dan kebaikan di akhirat dan jauhkan dari siksa api neraka". (HR Muslim dan Abu Hurairah)

Melalui do'a tersebut maka pada jiwa pemasar akan tumbuh optimis dan memperoleh kebaikan serta terhindar dari sekumpulan kejahatan dengan memohon perlindungan kepada Allah Swt. Berikut ada beberapa aspek yang perlu diperhatikan oleh pebisnis/pelaku pemasaran yaitu: a) Ta'awwudz adalah ungkapan memohon perlindungan kepada Allah dari malapetaka dan kejahatan yang ada di kehidupan dunia dan akhirat. b) Adanya pemahaman dan kesadaran bahwa harta adalah perhiasan dunia. Harta adalah sarana untuk memperoleh kebaikan. Dalam al-Qur'an Allah telah memberikan kepastian tentang orang yang beriman akan diberikan kecukupan. c) Menjaga harta dan melarang untuk berbuat berlebihan yang muaranya pada kemubadziran. d) Terbebas dari kemiskinan atau mencapai kesejahteraan (materi, mental dan spiritual). e) Keyakinan bahwa 
kemuliaan manusia di sisi Allah adalah bukan karena hartanya, melainkan karena ketakwaannya dan amalan-amalannya. Ketakwaan dan amalan baik bersumber dari hati.

2. Keadilan sosial

Keadilan menurut perspektif Islam merupakan akar prinsip. Keadilan diterapkan pada seluruh aturan-aturan yang ada dalam Islam, baik akidah, syari'ah maupun etika. Menurut Rahman ${ }^{4}$, prinsip keadilan dalam Islam secara umum menitikberatkan pada 3 aspek, yaitu: 1) keadilan dalam produksi yang ditunjukkan dengan adanya mewajibkan manusia umtuk bekerja sesuai dengan kemapuan, keahlian dan aktivitas yang disenangi guna mensejahterakan hidupnya, dan tetap beribadah pada Allah sekaligus melindungi yang lemah, 2) keadilan dalam konsumsi ditunjukkan dengan dilarangnya secara tegas sifat bakhil dan pemborosan, 3) keadilan dalam distribusi dan pertukaran ditujukan agar kekayaan tidak menumpuk pada sekelompok orang saja dan terwujudnya kemakmuran secara merata.

\section{Tatakrama perilaku bisnis (etika)}

Agama Islam tidak pernah memisahkan kegiatan muamalah dengan etika. Rasulullah Saw., sebagai nabi akhir zaman di utus oleh Allah Swt, untuk menyempurnakan akhlak (etika), sabda Nabi Muhammad Saw:

"Sesungguhnya aku diutus untuk menyempurnakan akhlak mulia." (HR Bukhari)

Etika bisnis yang ditata oleh al-Qur'an pada saat melakukan semua akad transaksi meliputi: 1) Adanya ijab qabul (tawaran dan penerimaan) antara dua pihak yang melakukan transaksi. 2) Kepemilikan barang yang ditransaksikan itu benar dan sah. 3) Komoditas yang ditransaksikan berbentuk harta yang bernilai. 4) Harga yang ditetapkan merupakan harga yang potensial dan wajar. 5) Adanya opsi bagi pembeli untuk membatalkan kontrak jika mendapatkan kerusakan pada komoditas yang akan diperjualbelikan. 6) Adanya opsi bagi pembeli untuk membatalkan

${ }^{4}$ Asnawi, Nur dan Fanani, Muhammad Asnan. 2017. Pemasaran Syari'ah: Teori, Filosof, dan Isu-isu Kontemporer. Depok: Rajagrafindo. Hlm 83. 
kontrak yang terjadi dalam jangka waktu tertentu yang disepakati oleh kedua belah pihak.

Beberapa istilah terkait dengan pemasaran syariah, antara lain: a) Kebijaksanaan: "hikmah" pengertian hikmah adalah memahami al-Qur'an (mengenal kebenaran dan mengamalkannya), meletakkan sesuatu pada tempatnya, dan selau sederhana (berusaha memahami sebab, dan meletakkan segala perkara sesuai porsinya). b) Kebutuhan: Islamic marketing didasarkan pada dua kebutuhan dasar seperti yang disebutkan dalam al-Qur'an yaitu kebutuhan fisiologis (makanan, tempat, air, dan pakaian) serta kebutuhan keamanan. c) Konsumen muslim, didefinisikan sebagai pola konsumsi, gaya hidup dan aturan keuangan yang diyakini sesuai dengan hukum-hukum Islam. d) Pasar: mekanisme pasar dalam Islam pada prinsipnya mematuhi hukum-hukum Islam di semua sektor. Produk yang tidak halal atau tidak mematuhi prinsip syariah tidak diizinkan dijual, misalnya produk yang mengandung daging babi dan alkohol. e) Perilaku yang baik: perilaku etis. f) Halal: "tayyibat". Mengandung kebajikan, suci, aman, halal dan produk menguntungkan. g) Kesepakatan bersama: adil dan bebas dari intervensi pembeli dan penjual serta tanpa pemaksaan. h) Kesejahteraan: "falah" kesuksesan dan kesejahteraan i) Iklan etis: tidak ada tindakan yang menyesatkan, penipuan atau kecurangan dalam iklan.

\section{Orientasi Bisnis Syariah}

Yusanto dan Widjajakusuma ${ }^{5}$ mengemukakan bahwa bisnis dalam Islam bertujuan untuk mencapai empat hal utama, yaitu: 1) Target hasil merupakan profit materi dan benefit-non materi artinya bahwa bisnis tidak hanya untuk mencari profit (qimah madiyah atau nilai materi) setinggitinginya, tetapi juga harus dapat memperoleh dan memberikan benefit (keuntungan) non materi kepada internal organisasi perusahaan dan eksternal (lingkungan). 2) Pertumbuhan merupakan hak perusahaan yang harus berupaya menjaga pertumbuhan agar selalu meningkat. Upaya peningkatkan ini juga harus selalu dalam koridor syariah, bukan

5 Asnawi, Nur dan Fanani, Muhammad Asnan. 2017. Pemasaran Syari'ah: Teori, Filosof, dan Isu-isu Kontemporer. Depok: Rajagrafindo. Hlm 90-91. 
menghalalkan segala cara. 3) Keberlangsungan merupakan target pertumbuhan yang dicapai setiap tahunnya dan harus dijaga keberlangsungannya agar perusaahan dapat eksis dalam kurung waktu yang lama. 4) Keberkahan, semua tujuan telah tercapai tidak akan berarati apa-apa jika tidak ada keberkahan di dalamnya. Maka bisnis Islam menempatkan berkah sebgai tujuan inti, karena ia merupakan bentuk dari diterimanya segala aktivitas manusia. Keberkahan ini menjadi bukti bahwa bisnis yang dilakukan oleh pengusaha muslim telah mendapat ridha dari Allah Swt, dan bernilai ibadah.

Bisnis merupakan kegiatan manusia yang bersifat universal. Makna universalitas bisnis berarti, bisnis bukan suatu hal yang hanya dimiliki oleh seseorang, bangsa, atau salah satu agama saja. Semua orang, siapapun dan apapun latar belakngnya berhak melakukan bisnis.

Allah Swt, memberikan kebebasan kepada makhluknya untuk melaksanakan kegiatan bisnis selama kegiatan tersebut dilakukan dengan yang tidak bertentangan dengan Islam. Berbisnis merupakan aktivitas yang tidak dilarang dalam Islam bahkan merupakan aktifitas warisan Rasulullah Saw, yang diperkuat oleh firman Allah Swt dalam al-Qur'an QS ash-Shaff [61]: 10.

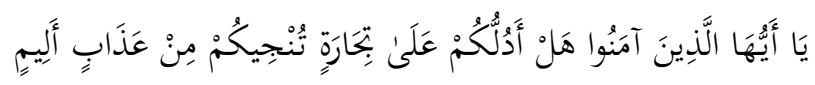

Artinya: "Hai orang-orang yang beriman, sukakah kamu aku tunjukkan suatu perniagaan yang dapat menyelamatkanmu dari azab yang pedih?"

Dalam al-Qur'an banyak ditemukan ungkapan ekonomi dan bisnis. Misalnya, ketika mengajak untuk beramal sering kali menggunakan istilahistilah yang dikenal dan berhubungan erat dengan bidang ekonomi dan bisnis. Demikian pula terdapat istilah-istilah seperti: bisnis, jual-beli, hartabenda, utang piutang, permodalan, usaha dan kerja, rezeki, keuntungan, upah, sewa-menyewa dan lain-lain. Al-Qur'an menawarkan suatu keuntungan bisnis yang tidak akan pernah mengenal kerugian dan penipuan sebagaimana tertuang dalam QS Fatir [35]: 29.

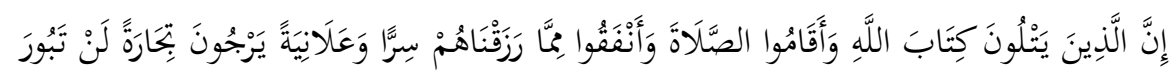


Artinya: "Sesungguhnya orang-orang yang selalu membaca kitab Allah dan mendirikan shalat dan menafkahkan sebagian dari rezeki yang Kami anugerahkan kepada mereka dengan diam-diam dan terang-terangan, mereka itu mengharapkan perniagaan yang tidak akan merugi."

Begitu pula dengan kegiatan ekonomi lainnya, secara lengkap diatur dalam al-Qurán. Termasuk juga larangan jual beli dari hal yang diharamkan dan memakan dengan jalan yang salah. Aturan mengenai cara yang diharamkan, dijelaskan dalam QS an-Nisaa' [4]: 29:

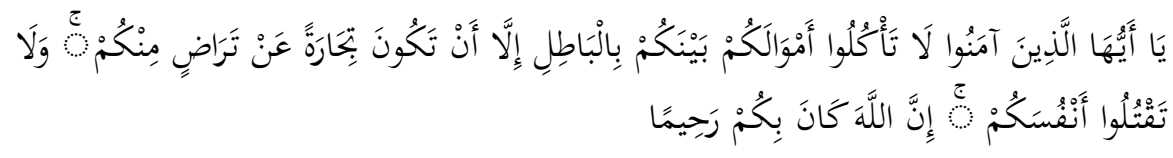

Artinya: "Hai orang-orang yang beriman, janganlah kamu saling memakan harta sesamamu dengan jalan yang batil, kecuali dengan jalan perniagaan yang berlaku dengan suka sama-suka di antara kamu. Dan janganlah kamu membunuh dirimu; sesungguhnya Allah adalah Maha Penyayang kepadamu.

Berdasarkan rangkaian penjelasan di atas ada beberapa guideline penting yang terkandung yaitu: 1) Al-Qur'an memberikan tuntunan bisnis yang jelas yaitu visi bisnis ke depannya yang tidak hanya semata-mata mencari keuntungan sesaat, melainkan mencari keuntungan yang hakiki dan berakibat baik pula bagi sesudahnya. 2) Keuntungan bisnis menurut al-Qur'an bukan sekedar bersifat material saja tetapi juga bersifat immaterial. Bahkan lebih mengutamakan hal yang bersifat immaterial atau kualitas. 3) Bisnis bukan semata-mata berhubungan dengan manusia tetapi juga berhubungan dengan Allah.

Tidak hanya memiliki kekuatan doktrin ajaran dalam al-Qu'an saja, tetapi juga di tunjang oleh suri tauladan kehidupan Nabi Muhammad Saw, baik sebelum masa kerasulan maupun setelah masa kerasulan. Nabi Muhammad Saw., telah meletakkan landasan-landasan praktik bisnis, etika, moralitas dan aturan-aturan dalam menjalankan bisnis. Kegiatan bisnis dilakukan dengan cara jujur, terbuka, saling menguntungkan, 
disiplin tinggi, rasa tanggung jawab dan jauh dari penipuan. Kesuksesan bisnis Nabi Muhammad Saw, berpegang teguh pada 4 kunci faktor yaitu: jujur, ikhlas, profesional, dan silaturahim.

Zaroni6 landasan normatif dalam perspektif Islam dibagi menjadi empat, yaitu:

1) Landasan tauhid (kesatuan). Konsep tauhid merupakan dimensi vertikal Islam sekaligus horizontal yang memadukan segala aspek di lini kehidupan manusia. Konsep ini menawarkan keterpaduan agama, ekonomi (bisnis), dan sosial demi membentuk kesatuan.

2) Keseimbangan (keadilan). Ajaran Islam berorientasi pada terciptanya karakter manusia yang memiliki sikap dan perilaku yang seimbang dan adil dalam konteks hubungan antara manusia dengan diri sendiri, dengan orang lain (masyarakat) dan lingkungan. Agar keseimbangan dalam praktik bisnis dapat terwujud maka harus ada pandangan yang benar tentang harta, yaitu: a) produksi, konsumsi, dan distribusi harus berhenti pada titik keseimbangan, b) setiap individu mempunyai nilai yang sama dipandang dari sudut sosial, c) tidak mengakui hak milik yang tak terbatas dan pasar bebas yang tak terkendali.

3) Kehendak bebas. Manusia sebagai khalifah di muka bumi mempunyai kebebasan untuk mengarahkan kehidupannya pada tujuan yang akan di capainya. Berdasarkan prinsip kehendak bebas ini, dalam bisnis manusia mempunyai kebebasan untuk membuat suatu perjanjian atau tidak, melaksanakan bentuk aktivitas bisnis tertentu, berkreasi mengembangkan potensi bisnis yang ada.

4) Pertanggungjawaban. Segala bentuk kegiatan yang dilakukan dalam bisnis oleh manusia tidak lepas dari pertanggung jawaban seasuai dengan apa yang ada di dalam al-Qur' an QS, al-Baqarah [2]: 281 dan alMuddastir [74]: 38 yang artinya: "tiap-tiap diri bertanggung jawab atas apa yang telah diperbuatnya".

Kekuatan bisnis dalam Islam adalah keimanan atau kepercayaan yang kuat tertanam dalam hati keesaan dan kekuatan anugerah dan rahmat Allah Swt. Bisnis dalam Islam harus mengutamakan keseimbangan

${ }^{6}$ Asnawi, Nur dan Fanani, Muhammad Asnan. 2017. Pemasaran Syari'ah: Teori, Filosof, dan Isu-isu Kontemporer. Depok: Rajagrafindo. Hlm 100. 
secara vertikal dan horizontal. Secara vertikal sebagai wujud komitmen dan bertanggung jawab kepada Allah Swt, dan secara horizontal harus mementingkan kemanfaatan dan kebaikan bagi sesama makhluk Allah Swt. Sehingga ketika seseorang berbisnis, maka Islam menekannkan kepada pelakunya untuk menghadirkan nuansa ketuhanan pada pelakunya. Berbeda dengan sosialis yang mengedepankan kekuatan bersama dengan negara sebagai pengendali untuk menggerakkan roda bisnis karena falsafah yang dipegang kuat adalah kebersamaan. Begitu juga dengan kapitalis yang sangat mengedepankan liberalisme dengan pemodal sebagai penggerak roda perekonomian yang melahirkan penguasa berasal dari pihak yang memiliki modal besar, bahkan cenderung melahirkan paham pragmatisme, yaitu paham yang berpandangan bahwa suatu ide, kata atau gagasan tidak mempunyai arti apa-apa selama tidak memberikan dampak dalam kegiatan nyata terutama ukuran pertimbangan untung rugi.

\section{Prinsip Bisnis Syariah}

Dalam Islam setiap pelaku bisnis harus memiliki prinsip yang kuat sejalan dengan syari'ah Islam. Prinsip inilah yang menjadikan seseorang menjadi tangguh, kuat dan tidak mudah terpengaruh dengan isu-isu di sekitarnya. Prinsip merupakan suatu pernyataan fundamental atau kebenaran umum maupun individual yang dijadikan oleh seseorang atau kelompok sebagai sebuah pedoman untuk berpikir atau bertindak.

Menurut Rivai7, prinsip perdagangan (bisnis) yang diajarkan alQur'an antara lain: 1) Setiap perdagangan harus didasarkan pada prinsip saling rela, tidak saling mendzalimi. 2) Menegakkan prinsip keadilan dalam hal takaran, timbangan, ukuran mata uang dan pembagian keuntungan. 3) Prinsip melarang riba. 4) Memiliki jiwa kasih sayang, tolong menolong dan persaudaraan. 5) Tidak melakukan investasi pada bisnis yang diharamkan agama, usaha yang merusak mental dan masyarakat. 6) Komoditas yang diperdagangkan memenuhi kaidah halal dan thayyib (barang/jasa yang berkualitas, suci dan memiliki dimensi

${ }^{7}$ Asnawi, Nur dan Fanani, Muhammad Asnan. 2017. Pemasaran Syari'ah: Teori, Filosof, dan Isu-isu Kontemporer. Depok: Rajagrafindo. Hlm 104-105. 
keindahan). 7) Terhindar dari praktik spekulasi, gharar, tadlis, dan maysir. 8) Perdagangan tidak boleh menjadikan manusia lalai dalam beribadah, termasuk zakat. 9) Dalam perdagangan baik secara kredit maupun cash hendaknya selalu dicatat.

Husaini $^{8}$ mengemukakan prinsip etos kerja yang diajarakan Rasulullah Saw terdiri dari empat prinsip: 1) bekerja secara halal (thalaba ad-dunya halalan). 2) Bekerja demi menjaga diri supaya tidak menjadi beban hidup orang lain (ta'affufan an al-mas'alah). 3) Bekerja demi mencukupi kebutuhan keluarga (sa'yan ala iyalihi). 4) Bekerja untuk meringankan beban hidup tetangga (ta'aththufan ala jarihi).

Prinsip-prinsip bisnis marketing meliputi, prinsip kesatuan (tauhid), prinsip kebolehan (ibadah), prinsip keadilan ( $\left.a l^{\prime} a d l\right)$, prinsip kehendak bebas (al-hurriyah), prinsip pertanggungjawaban, prinsip kebenaran, kebajikan dan kejujuran, prinsip kerelaan (ar-ridha), prinsip kemanfaatan, dan prinsip haramnya riba. Prinsip tersebut diuraikan sebagai berikut:

1) Prinsip kesatuan (tauhid). Prinsip ini adalah prinsip utama. Kegiatan apapun yang dilakukan manusia harus didasarkan pada nilai-nilai tauhid. Prinsip ini akan melahirkan tekad bagi pelaku bisnis atau pemasaran untuk tidak berlaku diskriminasi pada semua pelaku bisnis.

2) Prinsip kebolehan (ibahah). Prinsip ini memberikan kebebasan bagi pelaku pemasaran untuk melakukan kegiatan bisnis apa pun, kecuali jika terdapat dalil yang secara tegas melarang. Prinsip ini berhubungan dengan kehalalan dalam melakukan transaksi baik secara proses maupun objek yang ditransaksikan.

3) Prinsip keadilan ( $a$ - $^{\prime} a d l$ ). Prinsip menekankan pada pentingnya pelaku pemasaran untuk melakukan aktivitasnya lebih mengutamakan pada kemanfaatan. Islam memberikan kebebasan dalam melakukan transaksi, tetapi nilai keadilan, aturan agama dan etika tetap harus dipegang secara kuat.

4) Prinsip kehendak bebas (al-hurriyah). Kehendak merupakan keinginan fitrah manusia. Kebebasan adalah kontribusi yang diberikan Islam bagi manusia. Berdasarkan prinsip ini manusia sebagai pelaku pemasaran

${ }^{8}$ Asnawi, Nur dan Fanani, Muhammad Asnan. 2017. Pemasaran Syari'ah: Teori, Filosof, dan Isu-isu Kontemporer. Depok: Rajagrafindo. Hlm 105. 
diberikan kewenangan untuk melakukan kegiatan bisnis dengan cara melakukan janji, sehingga implikasinya adalah menepatinya walaupun sisi lain yang terkadang juga mengingkarinya.

5) Prinsip pertanggungjawaban. Kebebasan mutlak adalah sangat mustahil dalam dunia ini. Dalam Islam semua perbuatan manusia akan dimintai pertanggungjawaban di akhirat kelak, termasuk kegiatan bisnis yang dilakukan oleh manusia. Prinsip pertangungjawaban ini akan mengubah perhitungan dalam perspektif ekonomi dan bisnis. Hal ini dikarenakan segala sesuatu dituntut untuk terus mengacu pada prinsip keadilan.

6) Prinsip kebajikan kejujuran. Kebenaran dalam pelaksanaan bisnis meliputi: niat, sikap, perilaku proses akad, transaksi, penetapan margin dan keuntungan. Realisasi dalam prinsip kebajikan ini mendorong para pelaku bisnis untuk berikap terbuka dan ramah.

7) Prinsip kerelaan (Ar-Ridha). Prinsip ini mengedepankan pada kejelasan semua pelaku bisnis. Praktik bisnis yang ditekankan dalam Islam harus dilakukan dengan rela sama rela tanpa adanya paksaan dan intimidasi. Kaidah sama-sama rela (antarodhin mingkum) merupakan usnsur penting dalam melakukan perjanjian akad (ijab dan qabul).

8) Prinsip kemanfaatan. Islam mengutamakan prinsip ini. Dengan adanya aturan yang tegas dari Allah pastinya Allah sangat menyukai kemanfaatan daripada ke-mudharat-an.

9) Prinsip haramnya riba. Prinsip ini merupakan salah satu implementasi dari prinsip keadilan. Praktik riba ini dalam aktivitas ekonomi terdapat unsur dhulm (aniaya). Artinya praktik riba ini ada pihak yang mendzalimi dan pihak yang dizalimi. Persoalan riba tidak hanya menyangkut masalah ekonomi tetapi juga menyangkut moral. Oleh karena itu, Islam memberikan solusi dengan menerapkan prinsip mudharabah dan musyarakah dalam menjalankan bisnis dan investasi.

\section{Konsep Marketing Syariah}

Pemasaran salah satu praktik bisnis memiliki falsafah tersendiri. Konsep pemasaran bertujuan memberikan kepuasan terhadap keinginan dan berorientasi kepada kebutuhan konsumen. Ini berbeda dengan falsafah 
bisnis yang berorientasi pada produk dan penjualan. Konsep pemasaran adalah falsafah bisnis yang menyatakan bahwa pemuasan kebutuhan konsumen merupakan syarat ekonomi dan sosial bagi kelangsungan hidup perusahaan. Pemasaran adalah aspek penting dalam sebuah praktik bisnis. Pemasaran merupakan proses penyusunan komunikasi terpadu yang bertujuan untuk memberikan informasi mengenai barang atau jasa dalam kaitannya dengan memuaskan kebutuhan (need) dan keinginan (want) manusia. Proses dalam pemenuhan kebutuhan dan keingian manusia inilah yang menjadi konsep pemasaran. Mulai dari pemenuhan produk, penetapan harga (price), pengirirman barang (place), dan mempromosikan barang (promotion).

Dari beberarapa definisi pemasaran yang dikemukakan ahli maka dapat diambil kesimpulan bahwa pemasaran merupakan aktivitas yang terorganisir dalam rangka menciptakan, menawarkan, menukarkan produk atau jasa yang memiliki nilai. Interaksi dalam proses pemasaran bersandar pada konsep inti yang meliputi: kebutuhan (needs), keinginan (wants), dan permintaan. Pemasaran dalam konteks aplikasi yang familiar di masyarakat melibatkan berbagai entitas objek. Praktik ini terklasifikasi dalam 10 tipe yaitu dalam konteks pemasaran barang, jasa, pengalaman, event, persons, tempat, properti, organisasi, informasi dan ide.

Terdapat lima konsep yang melekat jika organisasi melakukan kegiatan pemasaran, yaitu: 1) konsep produksi (production concept) beranggapan bahwa konsep ini merupakan salah satu konsep tertua dalam bisnis dan menyatakan bahwa konsumen lebih suka produk yang tersedia secara luas (banyak) dan murah. 2) Konsep produk (product concept) menyatakan bahwa konsumen lebih menyukai produk-produk yang menawarkan kualitas paling tinggi, dan kinerja bagus dan memiliki fitur inovatif. 3) Konsep penjual (selling concept) menyatakan bahwa konsumen dan pelaku bisnis jika dibiarkan saja tidak akan melakukan pembelian produk dari perusahaan. Organisasi harus melakukan suatu usaha penjualan yang agresif dan usaha promosi. 4) Konsep pemasaran (marketing concept) menyatakan bahwa kunci untuk mencapa tujuan organisasi supaya lebih efektif daripada para pesaingnya adalah menciptakan, menyampaikan, dan mengomunikasikan nilai pelanggan 
terhadap target pasar yang dipilih. dan 5) pemasaran sosial (social marketing concept) menyatakan bahwa tugas organaisasi adalah menentukan kebutuhan, keinginan, dan kepentingan pasar sasaran (target market) dan memberikan kepuasan yang diinginkan secara lebih efektif dan efisien dari pada pesaing dengan tujuan melindungi atau meningkatkan kesejahteran masyarakat.

Perbedaan mendasar antara pemasaran dan penjualan terletak pada sikap dalam melihat bisnis. Konsep penjualan mengambil perspektif inside out. Dimulai dengan pabrik, berfokus pada produk yang sudah ada, dan panggilan yang menjual dan mempromosikan untuk menghasilkan kinerja penjualan yang menguntungkan. Konsep pemasaran mengambil perspektif inside in, dimulai dengan pasar yang terdefinisi dengan yang akan mempengaruhi pelanggan, dan menghasilkan keuntungan melalui penciptaan kepuasan pelanggan. Konsep pemasaran bertumpu pada empat pilar: pasar sasaran (target market), kebutuhan pelanggan (customer needs), pemasaran terpadu (integrated marketing), dan profitabilitas (profitability).

Perbedaan konsep penjualan dan konsep pemasaran

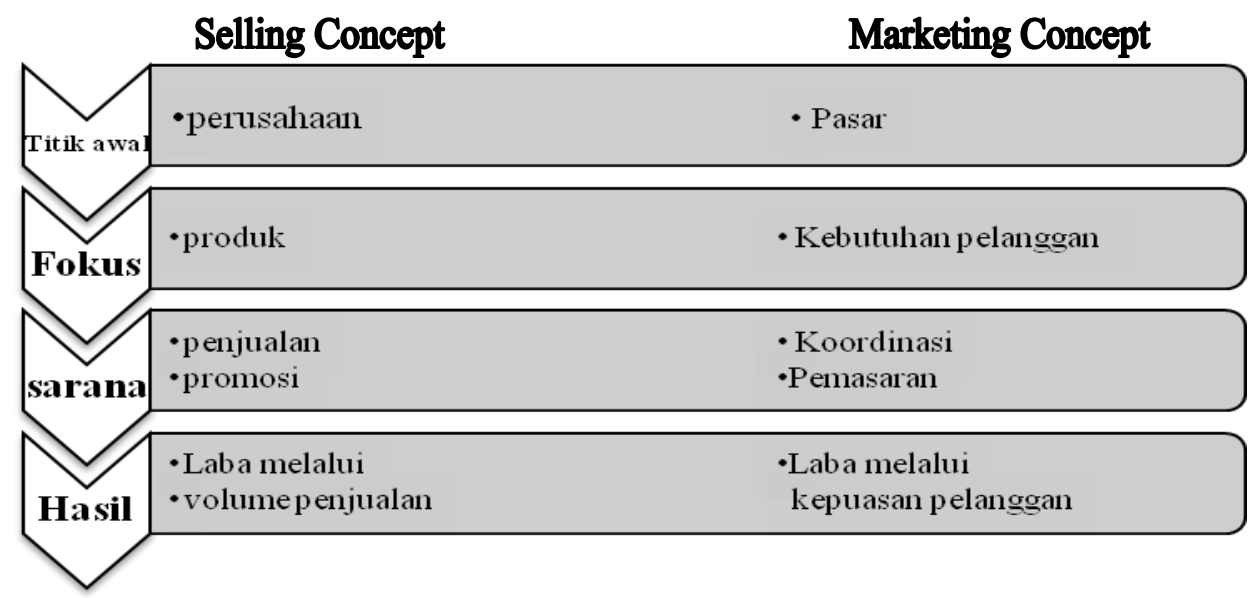

Pemasaran (marketing) adalah aspek penting dalam sebuah praktik bisnis. Praktik bisnis tidak hanya menitikberatkan pada persoalan penjualan produk (orientasi kinerja penjualan) yang berkualitas dan memenuhi kebutuhan (need) dan keinginan (want) pelanggan saja, namun juga terdapat proses jalinan komunikasi yang continue yaitu proaktif 
membina rangkaian jaringan bisnis melalui pemasaran produk atau jasa yang dapat berkesan pada pelanggan (loyalitas pelanggan).

Dalam kaidah Islam pemasaran yang baik adalah praktik pemasaran yang dilandasi oleh kaidah dan nilai-nilai Islam serta tidak bertentangan dengan sumber hukum Islam. Makna transendental dalam Islam, pemasaran yang baik dalam Islam adalah pemasaran yang dilakukan oleh pelakunya dengan berpegang teguh pada syariah Islam.

Islam tidak menghalangi pemeluknya untuk mendapatkan keuntungan dari kegiatan bisnis, namun usaha yang mendapatkan keuntungan harus diperoleh dalam ruang lingkup batasan-batasan yang telah digariskan oleh sumber-sumber dalam Islam yang meliputi al-Qur'an, hadits, ijma' dan qiyas. Dalam perspektif Islam banyaknya rezeki dan kekayaan tidak ditentukan menggunakan ukuran nilai nominal maupun jumlah barang, melainkan terwujudnya kesejahteraan dan ketentraman jiwa sebagaimana sabda Rasulullah Saw.

"Bukanlah kekayaan itu dibuktikan dengan banyaknya harta benda, tetapi kekayaan yang sebenarnya adalah kekayaan jiwa". (HR. Bukhari dan Muslim).

Dalam Islam keunggulan yang hakiki adalah apabila kita dapat meraih keuntungan dunia disertai dengan ridha Allah Swt atas hasil usaha yang maksimal yang sesuai dengan syariah serta keberkahan di dunia dan di akhirat. Melalui media bisnis, Rasulullah Saw mampu menjadi marketer yang dapat dipercaya, cerdas, serta mampu menjalin ukhuwah dengan seluruh lapisan masyarakat pada masa itu. Dengan media bisnislah banyak memeluk Islam sebagai bukti kekaguman pada nilai-nilai Islam.

Islam memiliki landasan utama dalam menjalankan praktik pemasaran adalah al-Quran. Kemudian sosok manusia yang dijadikan refrensi baik perkataan maupun perbuatannya adalah Rasulullah Saw. yang disebut dengan Sunnah, ada juga landasan yang juga relevan untuk digunakan yaitu kesepakatan para ulama (ijma'), ada lagi yang dapat digunakan sebagai rujukan yaitu analogi-analogi yang tidak bertentangan dengan al-Quran dan Sunnah (qiyas). 


\section{Tantangan Marketing Modern}

Perubahan dalam dunia pemasaran merupakan suatu keharusan lantaran dalam dunia bisnis sebagai induk dari pemasaran terus berubah menyesuaikan diri dengan kemajuan zaman. Walaupun mengalami peruabahan, pemasaran tidak bisa melepaskan diri dari tiga komponen yang selalu menyertainya, yaitu: konsumen (customer), kompetitor (competitor) dan perusahaan (company). Beberapa tantangan pemasaran yang terjadi di abad ke-21 antara lain:

1) Kemajuan teknologi. Revolusi membawa dampak yang sangat besar bagi sistem, nilai, cara, berpikir, wawasan, pola hidup, mobilitas, aktivitas dan lingkungan dimana manusia berada. Teknologi akan terus mengalami kemajuan yang sangat cepat. Setiap hari terus melakukan inovasi ke arah yang lebih cepat, lebih sederhana, lebih kecil dan lebih canggih guna mengakomodinir kebutuhan manusia. Peter F. Drucker mengklasifikasikan perubahan besar dalam tiga gelombang, yaitu: agricultural wave (penguasa di bidang tanah), industrial wave (kekuatan mesin), informational wave (revolusi teknologi informasi).

2) Globalisasi. Manusia tidak akan pernah tahu apa yang akan terjadi di hari esok. Manusia hanya memiliki kemampuan untuk merencanakan dan me-review apa yang telah dilakuakan kemarin. Oleh karena itu, Islam sangat menekankan perlunya berusaha sekuat tenaga disertai dengan berdo'a dan berakhir dengan berserah diri pada Allah Swt.

3) Deregulasi. Dengan semakin berkembangnya dunia teknologi informasi dan kuatnya pengaruh globalisasi maka juga akan mempengaruhi tatanan kehidupan, norma, nilai, budaya dan kebiasaan manusia. Termasuk peran pemerintah dalam menetapkan deregulasi. Semua itu akan berdampak pada mekanisme pemasaran, terutama dalam proses produksi, pola konsumsi, dan sekenario distribusi. Dalam produksi misalnya, produk yang diproses harus memenuhi kaidah halal dan suci. Dalam mengkonsumsipun demikian, dalam proses distribusi tentunya akan memperhatikan minimalisasi biaya dan ketepatan dalam menjangkau konsumen.

4) Pertumbuhan demografi umat muslim. Populasi muslim di seluruh dunia tumbuh dengan cepat dibandingkan kaum non-muslim. 
Perubahan demografi inilah yang membuat daya beli konsumen muslim dan keberhasilan pengusaha muslim membuat pemasaran Islam menjadi kajian ilmiah dan strategi manajerial yang menarik. Faktorfaktor yang mempengaruhi kecepatan pertumbuhan penduduk muslim antara tingkat kesuburan yang lebih tinggi (lebih banyak menghasilkan anak perempuan) daripada populasi non-muslim, banyak yang segera memasuki tahun-tahun reproduksi awal yaitu pada usia 15-29, meningkatnya kesehatan dan kondisi ekonomi di negara-negara muslim sehingga berimplikasi pada menurunnya rata-rata kematian bayi dan anak dan keadaan ekonomi.

5) Isu-isu global (politik, halal, fashion). Tidak dapat dipungkiri bahwa kebijakan politik dari negara adikuasa (negara-negara barat) yang berhubungan dengan dunia Islam akan membawa dampak pada pola perilaku konsumen muslim. Kemudian kebijakan tentang produk halal sebagai persyaratan mutlak untuk produk atau jasa dikonsumsi umat Islam juga menjadi isu sentral karena istilah "halal" pada produk maupun jasa sangat penting dalam Islam. Termasuk style fashion yang berkembang juga menjadi perhatian khusus bagi umat muslim terutama fashion yang sesuai dengan tuntunan syariah Islam. Isu-isu dunia fashion ini menjadikan isu krusial karena menyangkut tentang aurat (bagian wanita yang harus tertutup) dan style mode dunia yang feminim, elegan dan terkesan modern.

\section{Penutup}

Konsep dasar Islamic marketing menghargai kebebasan individu guna memperoleh keuntungan dari kegiatan bisnis, namun usaha untuk mendapatkan keuntungan harus dalm ruang lingkup batasan-batasan yang telah digariskan oleh sumber-sumber dalam Islam. Dalam Islam keunggulan yang hakiki adalah apabila dapat meraih keuntungan dunia disertai dengan ridha Allah Swt atas hasil usaha yang maksimal sesuai dengan syariah. Prinsip pemasaran dalam Islam meliputi prinsip ketauhidan (ketakwaan) yang menekankan pada keimanan pada Allah Swt dan Rasul-Nya, prinsip kesatuan manusia (keadilan) yang menekankan 
pada pentingnya memandang manusia sebagai ciptaan Allah Swt dan sebagainya.

Apabila bisnis ditinjau dari perspektif orientasi organisasi dalam mencari laba, maka bisnis dapat dibedakan menjadi dua juga yaitu organisasi bisnis yang orientasinya mencari laba, dan ada juga yang sifatnya non profit oriented. Berbisnis merupakan aktivitas yang tidak di larang dalam Islam bahkan merupakan aktivitas warisan Rasulullah Saw, yang diperkuat oleh firman Allah Swt. Dalam al-Qur'an istilah-istilah bisnis juga digunakan untuk menggambarkan hubungan antara manusia dengan Allah Swt.

Prinsip perdagangan (bisnis) yang di ajarkan al-Qur'an antara lain: 1) setiap perdagangan harus didasarkan pada prinsip saling rela, tidak saling mendzalimi, 2) menegakkan prinsip keadilan dalam hal takaran, timbangan, ukuran mata uang dan pembagian keuntungan, 3) prinsip melarang riba, 4) memiliki jiwa kasih sayang, tolong menolong dan persaudaraan, 5) tidak melakukan investasi pada bisnis yang diharamkan agama, usaha yang merusak mental dan masyarakat, 6) komoditas yang diperdagangkan memenuhi kaidah halal dan thayyib (barang/jasa yang berkualitas, suci dan memiliki dimensi keindahan), 7) terhindar dari praktik spekulasi, gharar, tadlis, dan maysir, 8) perdagangan tidak boleh menjadikan manusia lalai dalam beribadah, termasuk zakat, 9) dalam perdagangan baik secara kredit maupun cash hendaknya selalu dicatat.

Terdapat lima konsep yang melekat jika organisasi melakukan kegiatan pemasaran, yaitu: 1) konsep produksi (production concept), 2) konsep produk (product concept), 3) konsep penjual (selling concept). 4) konsep pemasaran (marketing concept), dan 5) pemasaran sosial (social marketing concept). Beberapa tantangan pemasaran yang terjadi di abad ke21 antara lain: kemajuan teknologi, globalisasi, deregulasi, pertumbuhan demografi umat muslim, isu-isu global (politik, halal, dan fashion). 


\section{DAFTAR RUJUKAN}

Aang, Kunaifi. 2006. Manajemen Pemasaran Syariah. Yogyakarta: Maghda Putaka.

Andriyani, Friska Amelia. 2013. Makalah Manajemen Pemasaran. Tersedia di http://friskameliandriyani.blogspot.com/2013/10/makalahmanajemen-pemasaran_6117.html. Diakses pada tanggal 8 September 2019.

Asnawi, Nur dan Fanani, Muhammad Asnan. 2017. Pemasaran Syari'ah: Teori, Filosof, dan Isu-isu Kontemporer. Depok: Rajagrafindo.

Huda, Nurul. dkk. 2017. Pemasaran Syari'ah: Teori dan Aplikasi. Depok: Kencana.

Kotler, Philip dan Keller, Kevin Lane. 2009. Manajemen Pemasaran, Edisi Ketiga Belas: Jilid 1. Ed. Adi Maulana dan Wibi Hardani, Jakarta: Erlangga.

Simanullang, Nelva. 2012. Lingkungan Pemasaran (Makro dan Mikro). Tersedia di http://nelvasimanullang.blogspot.co.id/ 2012/12/lingkungan-pemasaran-makro-dan-mikro.html. Diakses pada tanggal 11 September 2019.

Triani, Mutiara Wang. 2013. Dasar Pemasaran. Tersedia di http://mutiarayuang18.blogspot.com/2013/05/dasar-pemasaran. html. Diakses pada tanggal 9 September 2015. 